\title{
HUMAN SECURITY, TERRORISM AND ORGANIZED CRIME IN THE WESTERN BALKANS
}

\author{
Ms. Cristina TĂRTEAŢ $\breve{A}^{194}$
}

\begin{abstract}
In this study we have analyzed the paradigm of Human Security and how it differs from the more known idea of global security in the context of war, terrorism and organized crime in the Western Balkans. To emphasize this, we have presented the main terrorist threats and attacks that have occurred in countries like: Bosnia and Herzegovina, Croatia, North Macedonia and the Kosovo province, also presenting the complexity of factors that have contributed to the present geopolitical climate. Also, we have compared the number of organized crime groups in these countries and how they contribute to the state of corruption that leads to violence, poverty and inequality. In the end of this paper, we have proposed a series of potential solutions to merge both human and global security in order to create a safer Balkan community in the context of the European Union.
\end{abstract}

Keywords: Human Security, terrorism, organized crime, Western Balkans, European Union.

\section{HUMAN SECURITY AS A CONCEPT IN THE CONTEXT OF TERRORISM AND BORDER CRIMINALITY}

Human security is an emergent concept in the global security culture from multidisciplinary perspective which considers the security of individual as priority oppositeto that of state. This concept is multidisciplinary relying on an extended concept of security, borrowing elements from international relations, human development, strategic studies etc. This approach considers that global security may exist only when the individual has the possibility to possess a proper life standard and when does not feel threatened of potential military conflicts or terrorism acts. Also, the impact that the actions of individual have on the world are deemed threats for human security, for instance, this category can include global warming and climate changes ${ }^{195}$.

As a concept, "Human security" is one of the most significant terms that emerged from the period of the Cold War. The logic behind its introduction and proliferations was clear: the realist, "state-centric paradigm of security that championed the primacy of territorial integrity over that of the individual, seemed

\footnotetext{
${ }^{194}$ Ms. Cristina Tărteață is economist and Ph.D. student at Școala Națională de Studii Politice și Administrative, Bucharest, Romania.

195 Kaldor, Mary (1999) New and Old Wars: Organized Violence in a Global Era, Cambridge: Polity Press.1999, p. 6.
} 
increasingly anachronistic in a world where states no longer faced the existential threat that nuclear stand-off had perpetuated"196.

In this regard, the focus changed towards the individual as a entity of security, as a center from which all other adjacent concepts can be derived. This change was due to the fact that inter-state wars were now in most part obsolete but military concept still existed between certain groups of people. This new type of conflicts, resembling classical wars, can be seen to a high degree as an outcome that derives from the process globalization and the emergence of "intransigent nationalisms - destroyed infrastructure, involved the intentional targeting of noncombatants, further worsened and proliferated conditions of poverty, and promoted and drove criminal activities and illegal economies"3.

Although there is not much consensus on the definition of Human Security the basis of this concept arises from the United Nations Development Program's (UNDP) 1994 Human Development Report. In this document, in the chapter titled as the 'New Dimensions of Human Security', characterizing the term trough the expression "a child who did not die, a disease that did not spread, a job that was not cut, an ethnic tension that did not explode in violence, a dissident who was not silenced"4. In this sense, the universality of human security was stated, based on interdependent elements that focused more on prevention than on reactive measure. At its center, this concept was designed to touch upon two values stated in the 1945 UN Charter that encompassed freedoms from want and fear.

From other perspective, considering the importance and argumentation of this kind of security, there are critics that consider the general character of this paradigm as limiting exponentially the efficiency of implementation of such methods ${ }^{5}$. In this respect, the critics consider that human security, in the absence of a structural pattern, becomes a tool for all kinds of activists who want to promote their causes relying on such concept and less on the field of search which emphasizes the benefits of different kinds of security.

We must outline that this kind of security has nothing to do with military security or national safety, however, ideologically, it approaches on a much more complex level the issue of human being in the context of both. Therefore, human security criticizes and emphasizes the manner how the current security strategies and external politics influences negatively the individual, creating inequality, fair and sacrificing the fundamental rights of human being for a so-called state of geopolitical balance.

According to FRONTEX, Cross-border crime is defined as any criminal activity that is in conjuncture with what can be defined as a state's external borders and can infringe upon the security of individuals or sometimes upon countries' security elements. Some examples of this type of crime include, but are not limited to, drugs, tabaco, alcohol, human and weapon trafficking, smuggling

\footnotetext{
196 Roland Paris, "Human Security Paradigm Shift or Hot Air", 2001, p.87, http://aix1.uottawa.ca/ $\sim$ rparis/Paris.2001.IS.Human\%20Security.pdf
} 
certain dangerous materials or even wildlife trafficking. ${ }^{197}$ In this sense, we can see that transnational crimes in time have grown as a threat as a concept due to criminal organizations that have now began to extend their network as a result of globalization and some humanitarian crises (eg: the migration waves in Europe) and also due to a certain improvement in technology and communication that facilitates a easier way for criminals to outgrow their dark business operations.

Organized crime as a concept can be defined as a category of criminality done by transnational, national, or sometimes small area groups of individuals that are organized and structured in order to profit of illegal enterprises. One of the main factors that is specific to this category is the quality of this type of organization to structure itself internally as an organization in order to improve upon the operations and to structure complex networks of influence in society. As motivations, most organized crime groups such as the Italian Mafia or the Japanese Yakuza are interested in money and power, unlike other criminal organizations such as terrorist groups which are most likely motivated by religious ideology. ${ }^{198}$ In this sense, terrorism, which per se doesn't have a definition that is widely accepted by al state actors, can be understood as any criminal activity that is designed to induce or provoke state of panic (terror) at a large level, based on motivations that touch upon certain ideological principles, religious or otherwise. ${ }^{199}$ This type of criminality has proven to be one of the most challenging threats in the last decades, due to the increasing complexity of terrorist's methods and resources.

\section{TERRORISM AND ORGANIZED CRIME IN WEST BALKANS}

In the current context of dynamics of power in West Balkans, where the states in the area face the dilemma of aligning the national policies to those of European Union in the context of a potential adhesion and definition of own identity, the individual, being a victim of some systems that have not entirely passed to democracy and capitalism, being constantly threatened by the incidence of terrorism and organized crime.

The Western Balkans, conceptually, is often used in political science to define the territory that encompasses the Albanian state and the territories that used to belong to the Yugoslavian state with the exception of Slovenia. These states are: Albania, Bosnia and Herzegovina, Montenegro, North Macedonia, Serbia and the province of Kosovo. The relevance of this geo-political area is that it includes countries that are not part of the European Union but that are

\footnotetext{
${ }^{197}$ Frontex, Cross-Border-Crime, accessed on 10.05.2021 https://frontex.europa.eu/we-support/cross-bordercrime/

${ }^{198}$ United Nations General Assembly (December 9, 1994). "49/60: Measures to Eliminate International Terrorism".UN Doc. A/Res/60/49.

${ }^{199}$ Fact Sheets of the European Union, accessed on 10.05.2021, https://www.europarl.europa.eu/factsheets/ en/ sheet/168/the-western-balkans.
} 
considered to be the next step for further UE expansion, one of this states, Croatia, joining the EU on July 1st 2013. ${ }^{200}$

From a social-cultural perspective, Balkan Peninsula is marked by a strong and influent Muslim community with power of decision in several states of peninsula. Definitely, this is generally a favoring factor and does not necessarily trigger terrorist phenomena. Despite all this, since 1990 up to present, it has been noticed an advance of radical Islamic and related actions. We shall analyze in this chapter the incidence and acts of militantism of this kind in the main states affected from West Balkan.

In Bosnia and Herzegovina, the incidence of terrorism is rather high, this phenomenon considerably developing during Bosnian War between 1992 and 1995. In this conflict, an important role belonged to Muslim community which represents the majority in this area (approx. 44\%). The military conflict was developed in three camps, each receivingexternal support. The Muslim Bosnians were financially supported and with troops of militaries and voluntaries from Iran and Saudi Arabia, the Serbians were supported by orthodox countries and the Croatians were supported by catholic countries. The number of Islamic radical voluntaries called El-Mudžahid, is still debated as being between 300 and 6000 . On $13^{\text {th }}$ August 1993, the Bosnian Army created Kateebat al-Mujahidin (Fighting Saints Battalion) in order to control the mujahidin phenomenon who had come to fight for Islamic jihad against Christian forces. Although, at the beginning of conflict, they began withsupport missions, with the intensification of war, they fought with military forces of Bosnia.

The president of Bosnia and Herzegovina during the war, Alija Izetbegović was accused form breaching the law offering citizenship to such foreign worriors. Starting with2007, the current government of Bosnia created a commission that reviewed and analyzed 1000 individuals, recalling the citizenship of 420 of them up to present ${ }^{201}$. Analyzing this situation and the report of USA State Department pursuant to Peace Agreement of Dayton from 1995 which compels Bosnia to expel the radical militants, currently, around 200 mujahidin are living in Bosnia $^{202}$.

Several terrorist attempts occurred on the territory of this state after this period. For instance, in 1997, an attempt with trap car occurred in the town of Mostar wounding 29 individuals and causing significant financial damages. The bombers were members of El Mudžahid operating with the support of SHC (Saudi High Commission). They were capturedpursuant to the attempts of $11^{\text {th }}$ September and imprisoned in Guantanamo Bay. Another member of SHC Organization, Saber Lahman, was captured for organizing attempts againstUSA Embassy in

\footnotetext{
${ }^{200}$ Pyes, Craig; Meyer, Josh, "Bosnia Seen as Hospitable Base and Sanctuary for Terrorists". Los AngelesTimes. October 07, 2001.

${ }^{201}$ BBC News, "Bosnia fighters face uncertain fate". BBC. May 10, 2007.

${ }^{202}$ Kroeger, Alex, "Mujahidin fight Bosnia evictions", Los Angeles Times, July 18, 2007.
} 
Sarajevo on behalf of al-Qaeda and after a long process, he was also imprisoned in Guantanamo Bay. This attempt was followed by other, for instance, the one from $25^{\text {th }}$ October 2002 where a Wahhabi militant killed three persons or the one of $29^{\text {th }}$ October 2011 when another Wahhabi militant fired on USA Embassy ${ }^{203}$ in Sarajevo killing a policeman. In 2014 the police of Bosnia arrested an important representative of Islam as he was recruiting warrior for ISIS ${ }^{204}$.

We therefore notice a progression of terror actions with Islamic influence in this areaof Europe. Currently, in this geo-politic space, two militant groups are operating: Al- Qaedain Bosnia and Herzegovina and Bosnian mujahidin's.

In the province of Kosovo, the organization called the Salvation Army of Kosovo represented one of the strongest paramilitary organizations. Its objective was the separationfrom Yugoslavia and creation of Big Albania. Due to its actions during the war in the province of Kosovo between 1998 and 1999, 800000 Albanians were forced to abandon their homes. A significant financing of this organization was provided for by drug traffic, attested as well by USA State Department that in 1998 included this group in the category of terrorist organizations, showing as well the manner how they were coordinating the heroin traffic $^{205}$.

This army force was joined by a significant number of volunteers in Albania, Turkeyand North Africa, the majority being Islamic and coordinated by European Islamic leaders affiliated to al-Qaeda ${ }^{206}$. For instance, over 175 mujahidin of Yemen joined the case of the province of Kosovo in May 1998.

On $11^{\text {th }}$ August 2014, the police of the province of Kosovo arrested 20 citizens suspected of connections with terrorist organizations, several weapons and explosives beingencountered at their homes ${ }^{207}$. According to a report of April 2015, over 230 individuals joined ISIS crisis, going to Syria to fight with the terrorists.

In North Macedonia, one of the most successful military operations were the, Mountains Storm Operations", from $7^{\text {th }}$ November 2007 by Special Police Forces of Macedonia Republic against an armed Albanese ethnic group from the region of Tetovo whichwas maintaining connections with paramilitary groups of the province Kosovo. Pursuant to such operations, 13 combatants were captured and another 6 killed.

\footnotetext{
${ }^{203}$ Robert Mackey, Rick Gladstone, "Gunman Fires at U.S. Embassy in Sarajevo", The New York Times, October 28, 2011, http://www.nytimes.com/2011/10/29/world/europe/gunman-fires-at-us-embassy-in-sarajevo.html?_r=0.

204 Haaretz, "Middle East Updates Bosnian Imam on Trial for Recruiting ISIS Fighters", Feb 11, 2015, Http://www.haaretz.com/middle-east-news/1.641980.

${ }^{205}$ Committee on the judiciary house of representatives, "Threat posed by the convergence of organized crime, drug trafficking, and terrorism", December 13 2000, http://commdocs.house.gov/committees/ judiciary/hju68324.000/hju68324_0f.htm, p. 43.

206 Yossef Bodansky, "Bin Laden: The Man Who Declared War on America", Prima Lifestyles; 2nd edition, September 21, 2001, p. 398.

${ }^{207}$ Laurence Norman, "Kosovo Arrests 40 Suspected Islamist Militants", The wall street journal, Updated Aug. 11, 2014, http://www.wsj.com/articles/kosovo-arrest-40-suspected-islamist-militants-1407754434.
} 
Five years after such operation, on $12^{\text {th }}$ April 2012, five Macedonian ethnic citizens were shot and killed by Albanese ethnic individuals in the locality of Smilkovci near Skopje. The five bombers were captured and imprisoned for life on $30^{\text {th }}$ June $2014^{208}$. Pursuant to such attempt, North Macedonia organized the „Monster Operation” on $1^{\text {st }}$ May 2012 searching 26 properties and arresting 20 Islamic fundamentalists, most of them fighting previously in Pakistan and Afghanistan.

Croatia faced terrorist attempts as well, therefore, in 1995 in Rijeka a member of a fundamentalist Islamic organization used a trap car to destroy a police section. The number of victims reached 27, however, besides the bomber, there was not deceased. Pursuant to an investigation organized by the representatives of Croatia and CIA, one concluded that the attempt was organized by a Bosnian named Hassan al-Sharif Mahmud Saad who was planning another attack against NATO forces for December the same year.

On the 14th of December 2020, UNODC has published an extensive analysis of organized crime in the Western Balkans, that states that between 2012 and 2018 the number of court convictions for organized crime activity has risen by $12 \%$. In this sense, it has been shown that for most part that illegal activity like people smuggling, drug and weapon trafficking are usually committed by small networks of individual, rather than complex organizations with a high degree of centralized command. This data is relevant due to the fact that it sheds light on the efforts that law enforcement and intelligence agencies have to put in to fight against a large number of decentralized groups, in opposition to opposing fewer complex and more organized groups. On the other hand, the trend of higher conviction is also an indicator of the improvement of the security process in the Western Balkans. ${ }^{209}$

From the perspective of human security, we may notice that West Balkan area is highly problematic in the light of ethnic and religious tensions. In the absence of real solutions, the Albanese ethnic population is trying to acquire political and religious monopole in the area. Although European Union and mainly the United Nations, on a best effort basis, tries to normalize the diplomatic relations and reduce the sources of ethnic conflict, an increasing number of militants of al-Qaeda and ISIS profit by local political misbalance to promote a fundamentalist agenda by terrorism. The prior examples indicate that the current governments of Balkan countries, by military and police operations are advancing in destroying such networks and punishing the terrorists. This may be an indicator of increase of individual safety of citizens.

Besides the terrorism, the organized crime represents a significant problem

\footnotetext{
${ }^{208}$ Shanghai daily, Macedonian court sentences 6 men to life imprisonment for lakeside killings, Jul01, 2014, http://www.shanghaidaily.com/article/article_xinhua.aspx?id=227320.

${ }^{209}$ UNODC, Measuring Organized Crime in the Balkans, p. 97, https://www.unodc.org/documents/data-andanalysis/OC/Measuring-OC-in-WB.pdf.
} 
in the West Balkan area, but not in all states. For instance, since Croatia was not subject to any embargo, it does not face such problem as the neighboring countries. The experts estimate that the number of organized crime groups in Croatian Republic ranges between 1 and 10, although, considering their internal structure, they cannot be deemed ,organized" as there isno internal hierarchy ${ }^{210}$.

On the opposite pole of Croatian Republic, we find Bosnia and Herzegovina where organized crime represents a serious problem both for economic development and security of citizen. The largest networks of this kind were created during the war a structured on ethnic criteria although, when needed, such organizations were collaborating. Also, due to the embargo, Serbia faces 50 organized crime networks ${ }^{211}$. The province of Kosovo is in a similar situation, the Albanese factions controlling the routes of drugs and persons trafficbetween Turkey and Europe.

\section{CONCLUSIONS}

In the area of West Balkan, the human condition of individual and implicitly human security are essential issues with no solutions encountered during the last two decades. Evenat the end of the tragic military conflicts in the area, currently, there is the same high level of uncertainty and vulnerability. This area is also threatened by the incidence of terrorist groups of al-Qaeda and ISIS, as well as by the rests of totalitarian governments in the area were they allowed the development of organized crime groups.

The problem of regional security in the Western Balkan can be considerd an European priority due to the fact that security risks have increased in that region due to a more noticeable terrorist presence and also an increase in transnational crime. The states that form this territory are part of the UE vision for enlargement and any delay in increasing regional security can present serious consequences for extending European stability. On the other hand, the rapports mentioned in this paper show a cautiously optimistic development and progress in the ability of these countries to address these threats proportional and for now they are aligned with the UE policy timeframe.

In our opinion, we consider that a strategic approach which may include the principles of human security could generate a climate where military solutions fall on the second position, focusing more on the needs of individuals living in this geo-political area. Indeed,in the West Balkan, there were several terrorist attempts needing tough security measures, however, the essence of regional conflicts appears pursuant to historical disagreements between the ethnic groups.

From another perspective, we consider that the issue of security in Balkan

\footnotetext{
${ }^{210}$ Věra Stojarová, Organized Crime in the Western Balkans, “HUMSEC Journal”, Issue 1, p. 93.

211 Transcrime, The Contribution of Data Exchange Systems to the Fight against Organized Crime in the SEE Countries, "Final Report for the Office of the Special Coordinator of the Stability Pact for SEE", pp. 258- 259.
} 
states must be integrated and aligned to the Policy of Common Security of European Union since the great majority of states in this area are candidates or potential candidates for UE adhesion and geopolitically, they must aspire to reach the same objectives of human security.

Although the situation in this region is not currently a guarantee for human security due to several terrorist attempts and presence of a high number of organized crime groups operating in these territories, we may consider that there are optimistic perspectives to createa stronger Europe able to fight with West Balkan states for human security against internal and external strong threats.

\section{BIBLIOGRAPHY}

- America's Climate Choices: Panel on Advancing the Science of Climate Change; Board on Atmospheric Sciences and Climate; Division on Earth and Life Studies; National Research Council, Advancing the Science of Climate Change, Chapter Sixteen: National and Human Security, 2010, http://www.nap.edu/read/12782/chapter/20.

- Bodansky Y., Bin Laden: The Man Who Declared War on America, Prima Lifestyles, 2nd edition, September 2001.

- Bosnia fighters face uncertain fate, BBC News, May 10, 2007.

- Committee on the judiciary house of representatives, Threat posed by the convergence of organized crime, drug trafficking, and terrorism, December 13 2000, http://commdocs.house.gov/committees/judiciary/ hju68324.000/ hju68324_Of.htm.

- Fact Sheets of the European Union, https://www.europarl.europa.eu/ factsheets/en/sheet/168/the- western-balkans.

- Frontex, Cross-Border-Crime, https://frontex.europa.eu/we-support/crossborder-crime/.

- Kaldor M., New and Old Wars: Organized Violence in a Global Era, Cambridge: 1999, Polity Press.

- Kroeger A., Mujahideen fight Bosnia evictions, Los Angeles Times, July 18, 2000

- Laurence N., Kosovo Arrests 40 Suspected Islamist Militants, The Wall Street Journal, Updated Aug. 11, 2014, http://www.wsj.com/articles/kosovo-arrest40-suspected-islamist-militants- 1407754434.

- Pyes C., Meyer J., Bosnia Seen as Hospitable Base and Sanctuary for Terrorists, Los Angeles Times. October 07, 2001.

- Mackey R., Gladstone R., Gunman Fires at U.S. Embassy in Sarajevo, The New York Times, October 28, 2011, http://www.nytimes.com/ 2011/10/29/ world/europe/gunman-fires-at-us- embassy-in-sarajevo.html?_r=0. 
- Middle East Updates Bosnian Imam on Trial for Recruiting ISIS Fighters, Haaretz, Feb 11, 2015,Http://www.haaretz.com/middle-east-news/1.641980.

- Paris R., Human Security Paradigm Shift or Hot Air?, 2001, http://aix 1.uottawa.ca/ rparis/Paris.2001.IS.Human\%20Security.pdf

- Shanghai Daily, Macedonian court sentences 6 men to life imprisonment for lakeside killings, 2014, http://www.shanghaidaily.com/article/article_ xinhua.aspx?id=227320

- Stojarová V., Organized Crime in the Western Balkans, "HUMSEC Journal”, Issue 1.

- The Contribution of Data Exchange Systems to the Fight against Organized Crime in the SEE Countries, Final Report for the Office of the Special Coordinator of the Stability Pact for SEE, Trans crime.

- United Nations General Assembly on December 9, 1994 "49/60: Measures to Eliminate International Terrorism, UN Doc. A/Res/60/49.

- United Nations, United Nations Development Report, New York: United Nations Development Program.

- UNODC, Measuring Organized Crime in the Balkans, https://www.unodc.org/documents/data- and-analysis/OC/Measuring-OC-inWB.pdf.

- Wood N., Bosnia Plans to Expel Arabs Who Fought in Its War, The New York Times, August 2, 2007. 